\title{
Epidermal growth factor receptor (EGFR) and Stat3 signal through Kras and have mutually opposite effects on Cten
}

\author{
Saleh AlGhamdi ${ }^{*}$, M ILyas $^{2}$ \\ From 2nd International Genomic Medical Conference (IGMC 2013) \\ Jeddah, Kingdom of Saudi Arabia. 24-27 November 2013
}

\section{Background}

Cten is a protein located at focal adhesions and has been reported to be an oncogene in colon, breast, lung and gastric cancer [1-3]. We have previously shown than Cten is a target of K-ras in colorectal and pancreatic cancer [4]. In this study, we investigated whether two other proposed mechanisms i.e. EGFR and Stat3 signaling were involved in regulating Cten expression.

\section{Materials and methods}

EGF was used to stimulate the EGFR while the PD153035 to inhibit the EGFR. On the other hand, IL- 6 used to stimulate the STAT3 and siRNA for STAT3 was used for knockdown. The effect was confirmed using Western blot and QPCR and cell motility was assessed by transwell chambers.

\section{Results}

Initially we manipulated EGFR signaling by (i) stimulation with EGF and (ii) inhibition by the PD153035 in the colorectal cancer cell lines SW620 and C32. In C32, EGF stimulation resulted in up-regulation of Kras and Cten whilst exposure to PD153035 resulted in down-regulation of both Kras and Cten. EGFR activation and inhibition was reflected by, respectively, increased and decreased cell motility although the effect of EGFR activation was lost by Cten Knockdown. In SW620, which harbours a KRAS mutation, modulating EGFR activity in this way had no effect on either Kras or Cten. Stat3 signaling has also been reported to positively regulate Cten. We tested this in SW620 by directly knocking down Stat3 and exposing cells to interleukin-6 (an activator of Stat3). Stat3 knockdown

\footnotetext{
* Correspondence: alghamdisa7@ngha.med.sa

${ }^{1}$ King Abdullah International Medical Research Center (KAIMRC), Riyadh, KSA Full list of author information is available at the end of the article
}

resulted in increased Cten whilst Stat3 activation resulted in downregulation of Cten. Testing for Kras expression showed that Stat3 was negatively regulating Kras and this was reflected in the Cten expression. Functional analysis however showed that inhibition of Stat3 resulted in a reduction of cell motility in a Kras and Cten-independent manner.

\section{Conclusions}

We conclude that both EGFR signals through Kras to modulate Cten (and consequently ILK/FAK) and stimulates cell motility. Stat3 however negatively regulates Kras and consequently Cten although its net effect is to stimulate motility through an alternative mechanism.

\section{Authors' details}

${ }^{1}$ King Abdullah International Medical Research Center (KAIMRC), Riyadh, KSA. ${ }^{2}$ Division of Pathology, Nottingham University, Nottingham, UK.

Published: 2 April 2014

\section{References}

1. Lo SH, Lo TB: Cten, a $\mathrm{COOH}$-terminal tensin-like protein with prostate restricted expression, is down-regulated in prostate cancer. Cancer Res 2002, 62(15):4217-21.

2. Liao YC, Chen NT, Shih YP, Dong Y, Lo SH: Up-regulation of C-terminal tensin-like molecule promotes the tumorigenicity of colon cancer through beta-catenin. Cancer Res 2009, 69(11):4563-6.

3. Albasri A, Al-Ghamdi S, Fadhil W, Aleskandarany M, Liao YC, Jackson D, Lobo DN, Lo SH, Kumari R, Durrant L, Watson S, Kindle KB, Ilyas M: Cten signals through integrin-linked kinase (ILK) and may promote metastasis in colorectal cancer. Oncogene 2011, 30(26):2997-3002.

4. Al-Ghamdi S, Albasri A, Cachat J, Ibrahem S, Muhammad BA, Jackson D, Nateri AS, Kindle KB, llyas M: Cten is targeted by Kras signalling to regulate cell motility in the colon and pancreas. PLoS One 2011, 6(6):e2091.

\section{doi:10.1186/1471-2164-15-S2-P59}

Cite this article as: AlGhamdi and ILyas: Epidermal growth factor receptor (EGFR) and Stat3 signal through Kras and have mutually opposite effects on Cten. BMC Genomics 2014 15(Suppl 2):P59.

\section{Ciomed Central}

(c) 2014 AlGhamdi and ILyas; licensee BioMed Central Ltd. This is an Open Access article distributed under the terms of the Creative Commons Attribution License (http://creativecommons.org/licenses/by/2.0), which permits unrestricted use, distribution, and reproduction in any medium, provided the original work is properly cited. 